\title{
Study on Analysis of Curriculum Nonformal Education Institution to Increase Student Self Directed Learning
}

\author{
I. Hatimah, J. S. Ardiwinata, Y. Shantini \\ Department of Non formal Education, Universitas Pendidikan Indonesia \\ Bandung, INDONESIA \\ ihat_hatimah@yahoo.co.id
}

\begin{abstract}
Self directed learning became a goal in the implementation non-formal education program. Managers need to develop a curriculum that encourages students conduct self directed learning. The purpose of the research is to obtain: a) institution staff knowledge of the program curriculum, b) the program at each institution that encouraging self directed learning, c) management measures of learning undertaken by teachers to encourage self directed learning students, d) self directed learning achievement of students in the program in nonformal education. To achieve these objectives, this study used a descriptive study on non-formal education institutions to explain the problems that arise in the present tense and its development since a few years ago. The findings obtained from the study are: a) The level of understanding of educators and education personnel to the specifications of the curriculum organized able to be well understood, because the source of thought and understanding of the learning environment is the daily activities of teachers and educators in institutions non-formal education is, b) non-formal education program curriculum unit (PKBM, CGC and Smart House), designed based on two approaches centered curriculum and curriculum context. c) The measures are carried out in growing independence of learners, generally adapted to the local conditions of the learning environment. Socio-cultural aspects influence learning and the learning climate, in addition to the position of non-formal education units had to be transparent or access to the public, the public is given the widest access to the learning needs in PNF. d) Self directed learning that achieved by learners are vary, because each program conditions also influenced by the willingness of citizens to learn, the time and conditions
\end{abstract}

Keywords-Self Directed Learning, Curriculum, Non-formal Education Institution Introduction

\section{INTRODUCTION}

Government efforts create quality human resources requires hard work and the willingness of all parties to be able to catch up Indonesia in progress with other countries. The culture waiting, passively and accept a condition without maximum effort should be able to be modified so that it can encourage the emergence of active individuals who want to move forward and compete in progress. Educational institutions have a very important role in fostering characters mentioned above. Every educational unit must be able to design learning that encourages learners have the motivation and willingness to learn are constantly growing, not only limited in the school environment or other units but also in the world of work or in society. As with the essence that stated by John Dewey as learning by doing, where an educated should not stop learning and working.
The presence of institutions, or better known as the unit in non-formal education as an alternative educational services unit is expected to be a new spirit to make learning needs really actualized. Non-formal Education Unit comes through the system the embodiment of the will of the community to provide structure and studying the most appropriate tools, of, by and for the community that is designed as a continuous learning tool. But in fact some non-formal education units instead trapped in the education bureaucracy.

Guidance to the non-formal education units are institutional (managerial aspect) become urgent demands as long as these institutions have not yet established managerial system. Through these development efforts, the participation of the general public is expected to realize the sustainability of the institution to be independent in line with other non-formal educational institutions. Continuity and independence of the institution is expected to alleviate poverty, improve the knowledge and skills of local people, improving community life skills, which substantially contribute to improving the quality of human resources

This study focused on the study of the study program curriculum analysis by non-formal educational institutions, especially the CLC, Smart House, and CGC. The focus of the study is based on results of previous studies and observations will be limited to the implementation of non-formal education programs in non-formal education units

\section{FOCUS OF STUDY}

This research was aimed to know the curriculum in unit PNF program (CLC, Smart House, LKP) in improving self directed learning of students with the focus of the study as follows: Knowledge educators on curriculum specifications of each unit will be the convening of the program, The curriculum/program of study in each unit in encouraging self directed learning of students learn proxies, Step-by-step learning management carried out by educators in encouraging self directed learning people learn the program, Self directed learning that achieved by student on the program in non-formal education institution

\section{LITERATURE REVIEW}

\section{A. Community Based Education}

Based on the characteristics and trends of the current problems of non-formal education, the concept of Community Base Education (CBE) became one of the backrest in strengthening the framework of this study, CBE emphasized the importance of understanding the community, characteristics, needs, weaknesses and its strengths. On the other hand, CBE 
stressed also on ways of solving the problem by the public to exploit the potential of the environment (to help people to help them self). CBE, developed on some conception as follows 1) Education lifelong, 2) critical education that emphasizes improvement of people's basic capabilities, enhance existing capabilities, and participation in each activity ,,3) Andragogy and Learning organization. Services non-formal education program is an educational approach to the problem of public education that is based on the convergence and diversification / learning needs with a variety of learning resources in the community to form a learning system.

\section{B. Life long Education}

Lifelong learning is an idea or concept, even recommended as a parent concept in educational innovation efforts. In other words, lifelong education is not a path or unit or program (as defined in the Law on National Education System No. 20 in 2003), but as an idea that underlie the development of pathways or educational unit. It is necessary to emphasize that the national education is carried out through three channels, namely formal education, non-formal and informal.

The notion of lifelong learning becomes a motivation or encouragement for individuals in the community to learn continuously through formal education, non-formal and informal. As stated by Sudjana (2004), that lifelong learning focused on the motivation for a person or group to gain learning experiences in a sustainable manner, where the learning experience is pursued consciously, programmed, and systematically through the process of learning activities in order to achieve the learning objectives (Sudjana, 2004: 228).

Many experts argue that independence is an entrepreneur spirit that grow and evolve with the understanding and concept of life, which leads to the ability, willingness, tenacity, perseverance in the field to pursue in the respective fields. So that a successful entrepreneur means having independent spirit.

Cain and Tumors (Ratnaningsih, 2007: 38) is independent learning is a dynamic process where students build knowledge, skills, and attitudes when studying the specific context. For that students need to have a variety of learning strategies, experiences to apply in different situations, and is able to reflect effectively.

Sumarmo (2004) told about the indicators in independent learning as follows: 1) Learning Initiative, 2) Diagnosing Learning Needs, 3) Setting Targets and Goals Learning, 4) Monitor, Manage and Control, 5) Seeing Difficulties As a challenge, 6) Utilizing and Finding Sources of relevant, 7) Selecting and Implementing a Learning Strategy, 8) Evaluating the process and Outcomes Study, 9) self Efficiency (selfconcept)Units

\section{METHODS}

The study was conducted using a descriptive study of the object of study of non-formal education institutions in order to provide an explanation of the issues surrounding emerging in the present tense and its development since a few years ago. Data collected by the conceptual framework that has been agreed upon, this data is required to refine the analysis so that studies can reveal in depth, accurately and objectively in accordance with the objectives of the study. Data collection techniques used in this study consists of the study of documentation, literature, and study of primary data and FGD (1) The study documentation, which collects qualitative data on the sources of curriculum documents, policies and administration of learning in the unit; (2) The study of literature, namely the collection of qualitative information pertaining to the theories and concepts of management and coaching PKBM, CGC and Smart Houses in the form of standard literature, research results, and the results of policy analysis; (3) Study of Primary data, namely data collection using questionnaires collected from respondents relating PKBM program in the unit, CGC and the Smart House. This data is necessary to know some knowledge and understanding of the PTK will be the program's curriculum; (4) Focus Group Discussion (FGD), is the data collected through the discussion of the parties are considered to know and understand the issues in learning for learning independence in unit PNFI implemented.

Area of research in the District / Bandung, West Bandung, Cimahi and Sumedang. The zoning is taking into account the criteria of ease in coordination with the manager is expected to provide complete information about coaching at non-formal education unit. The research subject is the program manager of non-formal education units, namely PKBM, CGC and Smart House.

\section{RESEARCH RESULT}

\section{A. Knowledge of Teachers and Education in the Curriculum of the Program Unit;}

Based on interviews, illustrated that all managers and educators in non-formal education units (PKBM, Smart House and CGC) has understood the program curriculum at the institution. Curriculum of each unit of non-formal education program is the result of the assessment of the environment and the needs of learners. But some of the curriculum provided by the government, as an example is the Competency Based Curriculum (CBC) that are intended for the LKP, according to the type of skills. However, CGC also has the authority to develop a curriculum that is both contextual and community needs. Statement of educators and managers understanding of the curriculum, is shown with an explanation of the foundation of the curriculum, such as:

- Psychological condition and characteristics of learners expressed in forms of behavior and interaction with the environment. Thus, need to be designed curriculum centered on increasing the capacity of learners to the market needs and the challenges of globalization. In line with the opinion of the NurAhid, Johnson stated (2006: 14), that experience will only appear when there is interaction between students and their environment. Such interaction is not a curriculum, but teaching. While the curriculum only with respect to the results of the study are expected to be achieved by students.

- The influence of technology, industry, communications, telecommunications, electronics, today are growing very rapidly toward an open society, and the global 
information society. Resulting in changes in work patterns, the changing role of women, and changes in family life.

- The development of science is now growing rapidly, covering all aspects of life, political, economic, social, cultural, religious, ethical and aesthetic, safety and even science itself. In line with the opinion of Jerome Bruner in NurAhid (2006: 22) that the design of the curriculum should be based on the structure of science,

- Education is always towards the future even using past and present. So that implementation of the curriculum is the result of social reconstruction that is integrated with the educational process. Because education can organize and control social development by using the technique of "social engineering" to the society aspired. According to NurAhid (2006: 24) conception of social reconstruction curriculum has influence, change, and give a new shape to society and culture.

\section{B. Learning Programs On Each Unit In Encouraging Self Directed Learning Of The Students;}

Learning programs organized each PNF is not the same, vary according to the needs and potential of local communities. As explained by Emil Durkheim in Mohammad Ali (2006: 110) that the meaning and development of independence from the point of view centered on the community. PNF program implemented budget comes from three, namely: self-financing budget, CSR and blockgrand from the government budget. In general, based on the study PNF studied, obtained by the programs implemented by the PNF, such as:

\section{- Community Learning Centre}

Learning activity in community learning centre are 1) Equality Programme such as Package A (Equivalent SD), Package B (Equivalent SMP), Package C (Equivalent SMA), 2) Life Skill Programme (Life Skills), 3) Course Programme, 4) Women's Empowerment Programme, 5) Gender Programme, 6 ) Literacy Education Programme (illiteracy eradication), 7) The group of art galleries and the like, 8) Tutoring, 9) Early Childhood Education Programme (ECD), 10) Community Library (TBM) Program

- Courses and Training Institutions

Learning activity in courses and training institution are 1) Computer courses, 2) English or other foreign languages Courses, 3) Sewing Courses, 4) Tutoring Program, 5) Makeup and Bridal Courses, 6) Hair Beauty Courses, 7) Skin Care Courses, 8) Music Courses, 9) Training for Marriage Preparation, 10) Catering Program, 11) Program in Accounting, 12) Program Automotive, 13) Program SPA, 14) Training driving, 15) Training Hospitality, 16) Training Electronics, 17) Training Acupuncture, 18) Training of tourism, 19) Training Public Speaking, 20) Training Printing Product, 21) Training for Garment.

\section{- Smart House}

Implementation of the program in units of Smart Home Solutions (Rumpin) for community learning, such as 1) Community Library 2) Informative and Educational Centers,
3) Center Playground, 4) Center Stage, 5) Craft Center, 6) IT centers

\section{Learning management steps undertaken by educators in encouraging students to have Self Directed Learning}

The steps taken in the management of learning in each unit $\mathrm{PNF}$, in particular to encourage self directed learning in general through the stages, as follows:

\section{- Planning Step}

Planning includes a series of activities to define the general objectives (goals) and special purpose (objectives) of an organization or institution that nonformal education providers based on complete information support. As confirmed by the Gaffar in Sagala (2010: 141), planning is defined as the process of preparing decisions that will be implemented in the future to achieve the objectives set while according Banghart and Trull in Sagala (2010: 141), planning is beginning of all rational process and contains optimistic nature that is based on the belief that it would be able to cope with various problems. Once the objectives are set, plans relating to the preparation of patterns, circuits, and process activities that will be undertaken to achieve these objectives. In short, planning with regard to the preparation of a series of activities to achieve the goal of organizing non-formal educational institutions. At this planning stage, is generally to stimulate the citizens to learn independence, which was to determine reward and punishment for residents learning achievement and inactive. In addition, some units prepare materials related to build motivation and self-learning management that are intended for residents to learn, so conditioning independent study has been prepared by the learners prior to the implementation of learning programs.

\section{- Implementation Step}

Learning approach in realizing the independence of learners, in general, is often done by PNF is communication; leadership; and create a climate conducive to the organizers and executors of educational activities. Directing and controlling can be included in the mobilization. At this stage, self directed learning aspect is also determined by the learning strategies implemented by educators, especially in the management of learning. Learning management saturated, the reason for citizens to learn not to pursue or follow the next learning program.

During the planning is done, mobilization plays an important role. Actuating a role also in other management functions, such as coaching; assessment; and development. Actuating function is to achieve the level of performance and a high participation of every executive involved in activities to achieve the goals set. Thus, mobilization can also be said as a learning strategy like motivation, can be achieved through efforts to grow and develop; spirit; confidence; and participation; or with respect to human values of each party involved in the learning process. In line with the opinion of Abdulhak (2000: 43) as follows: "Strategies in learning activities 
can be interpreted from two approaches, which are narrow and broad. Narrowly strategies have in common with the method, which means learning how to achieve the goals that have been set. Broadly, strategy defined by setting all aspects related to the achievement of learning objectives included in the preparation of the planning, implementation of learning activities, and assessment processes as well as learning outcomes

\section{- Evaluation Step}

Assessment of learning outcomes can be done during the learning process, ie tutor recorded everything that happened on that day which made assessment materials at the end of the activity or theme. In addition, the assessment is done to determine the extent of the activities in achieving the objectives and activities deviation from the plan that has been drawn up. Results of this assessment be material in the future development of learning programs, both related to methods of learning; material; the means used; as well as other matters relevant to the management of learning programs will be better again in the future

Assessment relating to the activities of collecting, processing, and presentation of information to be used as input in decision making. Target assessment can include: 1) the overall management function, from planning to development; 2) all components, processes, outcomes, and the effect of a nonformal education program. The assessment continues and is directed to determine the level of achievement of the stated goals; the activities in achieving the goals; and deviations from planned activities have been prepared. Results of the assessment be a feedback for decision-making. Thus, assessment plays a role in raising; process; and provide information for decision making regarding the effort justification (adjustment); repair; implementation; and development activities. In line with the opinion of Munir (2009: 108) states that: "evaluation of learning: learners create evaluation materials, ie by mapping out material or instrument of evaluation of the learning objectives that have been defined previously, using texts and reading materials and learning resources. Learners must cooperate actively for the success of the learning, because the text is the key to the success of online learning. In the evaluation of the project approach, it is necessary for the project rubric learners

\section{Self Directed Learning that Achieved by Student}

Self directed learning in non-formal education program, an attitude is the conditioning of learning so that learners are required to have a liveliness, its own initiative in learning and behave. The growing independence of ourselves, to obtain specific needs /destination, the opinion is in line with Yasin Setiyawan (2007: 1) that independence is a state of a person who can determine themselves which can be expressed in actions or behaviour of a person and can be assessed.

A form of independent learning that occurs in non-formal education units, can generally be shown in attitude as follows:

- Learners strive to be responsible in making decisions
- Learners tried jointly or in cooperation with a group

- Learners feel motivated, if the learning process goes well, the communication is done between learners with educators goes well, done through the activity of discussion, dialogue, group study, group practice.

- Learners are able to share their experience and knowledge to fellow students, teachers and the community.

- Learners utilize a variety of resources, such as books at TBM, study groups, joint exercises, see simulations in some on-line media like you-tube and other print media.

- Learners learn with confidence

- Learners plan and choose their own learning activities.

Independence of learners in unit PNFI, influenced by internal factors learners themselves, such as: motivation, selfconfidence, discipline, responsibility and initiative learners themselves.

\section{CONCLUSION}

Non-formal education curriculum unit, is divided into two approaches, the curriculum had been developed or designed by the government, PNF implement the curriculum or modify it. There is also a contextual curriculum that is based on the needs of the community, based on mutual agreement. Educator understanding of relevant curriculum developed and implemented, it has been well understood.

Learning programs are implemented by non-formal education units, depending on the needs of the community. CLC unit to focus more on the development of broader learning content, CGC to focus more on the development of learning content of vocational or life skills, while the Smart House has had a community learning centers.

At this stage of learning management, learning to realize the independence of course, begins with the conditioning of learners at the planning stage. Learners are given a briefing on the motivation and self-learning tips, learning time management and other learning techniques. Thus, through the conditioning process, learners are ready to receive learning materials.

Independence of learners in each PNF, certainly varied. It is also determined by internal factors learners themselves. Internal factors learners built also in the early stages or during the learner orientation, although any learning process can not be separated from efforts to motivate learners.

\section{REFERENCES}

[1] Abdulhak, Ishak (2000). Metodelogi Pembelajaran Orang Dewasa. Bandung: CV Andira

[2] Franklin Babbit. (1981). The Curriculum. Boston: Hounghton Mifflin.

[3] Mohammad Ali dan Mohammad Asrori. (2006) PsikologiRemajaPerkembanganPesertaDidik. Jakarta: PT BumiAksara.

[4] NurAhid. (2006). KonsepdanTeoriKurikulumdalamDuniaPendidikan.Universitas Islam NegeriSunanAmpel.JurnalIslamica Vol. 1 No 1 November 2006.

[5] Sagala, S. 2010. Konsep dan Makna Pembelajaran. Bandung: Alfabeta 
[6] Sudjana, H.D. (2004). Pendidikan Non Formal: Wawasan, SejarahPerkembangan, Filsafat, TeoriPendukukung, Asas,.Bandung: Falah Production.

[7] Sumarmo (2004). Kemandirian Belajar: Apa, Mengapa, Dan Bagaimana Dikembangkan Pada Peserta Didik. Makalah Seminar Pendidikan Matematika, Tanggal 8 Juli 2004. Di Universitas Yogyakarta

[8] YasinSetiyawan.

(2007).

PerkembanganKemandirianSeorangAnak.IndeksArtikelSiaksoft, posted by. Edratna 28 Juli 2007 